\title{
Application of Remote Sensing Tools for Land Resource Inventory of Kannur Micro Watershed Kollegal Taluk, Chamarajnagar District, Karnataka, India
}

\author{
Ravindra Naik, $\mathbf{M}^{1}$, Anilkumar, K. S. ${ }^{2}$ \\ ${ }^{1}$ Department of Soil Science and Agricultural Chemistry, UAS, Bangalore-560 065, Karnataka, India \\ ${ }^{2}$ ICAR-National Bureau of Soil Science and Land Use Planning, R.C. Bangalore-560 024, Karnataka, India
}

\begin{abstract}
Application Of RS Tools For land resources of the watershed was carried out by using cadastral map (1:10 000 scale) as base. Apart from the cadastral map, remote sensing data products from IRS LISS IV (5.8 m resolution) and Cartosat-1 (2.5 m resolution) were used to identify the landforms and other surface features of Kannur watershed, Chamarajnagar District, Karnataka belonging to Southern Dry Zone. Eight soil profiles representing the study area were selected based on the topography from various physiographic units identified in the area by field survey. Depth of the soils ranged from moderately deep to very deep, colour varied from reddish brown to dark red in uplands and yellowish brown to dark grey in lowland. The texture of the soils was from sandy clay loam to sandy clay. The common structure was weak, fine, sub angular blocky in surface horizons, while moderate medium sub-angular blocky in subsoil. Soil reaction varied from slightly acidic to strongly alkaline (6.2 to 8.7). The organic carbon and CEC of the soil varied from low to medium; 0.2 to 0.65 per cent and 5.0 to $33.9 \mathrm{cmol}(p+) \mathrm{kg}^{-1}$ respectively. The upland physiographic units were low in CEC values than midlands and lowlands owing to their low clay content, low organic matter and predominance of 1:1 type of clay minerals, whereas lowlands exhibited moderate CEC values due to higher clay content. The available nitrogen, phosphorus and potassium were low, low to medium and medium respectively.
\end{abstract}

Keywords: RS Tools, Land resource inventory, Toposheets, Cadastral Map

\section{Introduction}

The ability of the land to produce crops is set by soil, climate and landform conditions, which in turn is dependent on intrinsic characteristics, agro-ecological settings, use and management (FAO, 1993). Despite the significant growth in production, the sustainability of some cropping systems has been showing signs of fatigue. Therefore, comprehensive account of our land resources and its potential and problems towards optimizing land use on sustainable basis is necessary. In the recent past, productivity of agricultural soils worldwide in general is on the decline. This prompted the per capita availability of food grain to fall from $510 \mathrm{~g}$ per day (1991) to $463 \mathrm{~g}$ per day (2004). Keeping these considerations in view, an investigation was carried out for Kannur micro-watershed in Kollegal taluk of Chamarajanagar district to assess the chemical and morphological, physical and physio -chemical characteristics of soils.

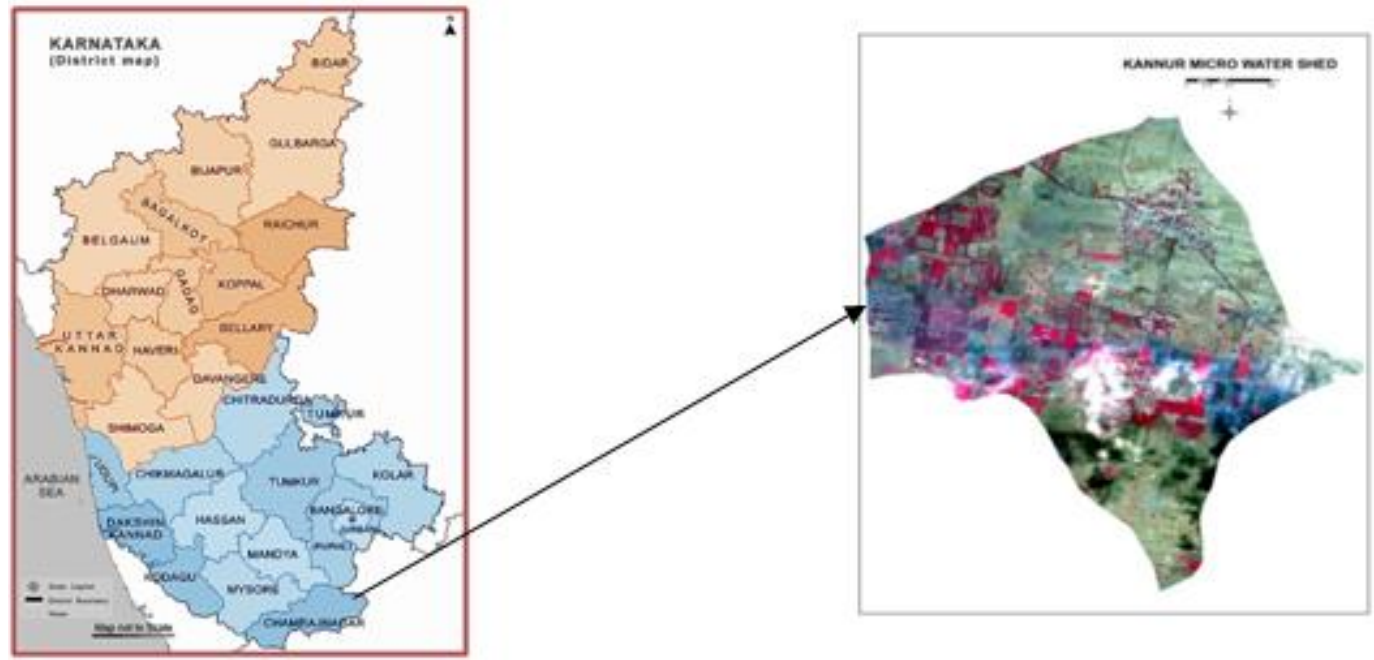

Figure 1: Location of study area in Karnataka 


\section{International Journal of Science and Research (IJSR) \\ ISSN (Online): 2319-7064}

Index Copernicus Value (2013): 6.14 | Impact Factor (2015): 6.391

\section{Materials and Methods}

The study area, Kannur watershed is located in Kollegal taluk, Chamaraj nagar district, falls under southern dry zone, with semi-arid climate with a dry period of around 6 months in most years. Micro-watershed located between $12^{\circ} 6^{\prime} 34.5^{\prime \prime}$ and $12^{\circ} 7^{\prime} 49.6^{\prime \prime} \mathrm{N}$ latitudes and $77^{\circ} 15^{\prime} 30.9^{\prime \prime}$ and $77^{\circ} 14^{\prime}$ $20.2^{\prime \prime} \mathrm{E}$ longitudes. The yearly annual rainfall varies from 650 to $840 \mathrm{~mm}$. It occupies parts of the four villages viz., Kannur, Anapura, Mangala, and Kamgare.

\section{Climate}

The climate of the study area is tropical monsoon type with mean annual air temperature of $24{ }^{\circ} \mathrm{C}$ and mean annual rainfall of $801.4 \mathrm{~mm}$ (1980-2011), Length of growing period commence from last week of May and continues up to end of October. Soil Moisture Control Section (SMCS) of watershed area falls under Ustic moisture regime with Mean Annual Summer Temperature (MAST) and Mean Annual Winter Temperature (MAWT) differ by less than $6{ }^{\circ} \mathrm{C}$, while analyzing data for about 30 years (IMD, 2012). The availability of moisture is a limiting factor for crop production, which in turn is determined by climate along with physiography and soil type.

\section{Methodology}

The detailed survey of the land resources of the watershed was carried out by using cadastral map (1:10 000 scale) as base. Apart from the cadastral map, remote sensing data products from IRS LISS IV (5.8 m resolution) and Cartosat1 (2.5 m resolution) were used to identify the landforms and other surface features. The imagery has been visually interpreted for identification of different landform units based on image interpretation keys like tone, texture, shape, size and association. Preliminary traverse was carried out by using 1:10,000 cadastral maps. During the traverse, based on surface features different landform units were demarcated and initial legend was prepared by studying soils in few selected places/road cuts. After this, intensive traversing of each landform unit i.e. hills, ridges, uplands and lowlands etc. was carried out. Based on the soil variability observed on the surface, transects were selected along the major slope direction, covering all landform units. In the selected transects, profiles were marked at close intervals to take care of changes in the land features like break in slope, texture etc. In the selected sites, 8 soil profiles were dug $(1.5 \mathrm{~m} \mathrm{x} 4$ $\mathrm{m} \times 1.5 \mathrm{~m}$ ) and studied in detail for all their morphological characteristics. The soil and site characteristics were recorded for all profile sites on standard proforma as per the guidelines given in USDA Soil Survey Manual (Soil Survey Staff, 2004). Based on the soil-site characteristics, the soils were grouped into eight different soil series. The area under each series was further divided into phases and their boundaries delineated on the cadastral map based on the variations observed in the texture of the surface soil, slope, erosion, presence of gravels and stones and coverage rocks. The soil samples from each horizon of pedons were collected and analyzed for important physical and chemical characteristics. Particle size distribution was determined by international pipette method (Piper, 1944). Soil reaction, electrical conductivity, exchangeable cations and cation exchange capacity were determined as described by Jackson (1973). Organic carbon was determined by wet oxidation method (Walkley and Black, 1934).The soils were classified as per USDA Soil Taxonomy (Soil Survey Staff, 2003).

\section{Results and Discussion}

\section{Morphological characteristics}

The results of the morphological, physical and chemical characteristics of soils of Kannur micro-watershed, Kollegal taluk, are presented in the tables 1 to 3 . Soil depth varied from deep to very deep, Soil colour varied from dark red to dark brown in red soils and very dark grey in black soils. Texture varied from sandy clay loam to clay. The red and black soil pedons exhibited moderate, medium, sub-angular blocky structure. Moist consistency varied from friable to very friable in red soil pedons and from firm to extremely firm in black soil pedons. Consistency was directly related to nature and amount of clay. Friable moist consistency in red soil pedons indicated good soil-water- air relationship. Thin patchy clay skins were visible on the ped surfaces and around sand grains of lower horizons of red soil pedons (P1, P3, P5, P6, P7 and P8). Slickensides were common feature in black soil pedons (P2) because of argillo-pedoturbation. Abundance and intensity of slickensides were more in middle of solum, because of maximum swelling pressure. Similar results were also reported by Dasog and Hadimani (1980).

\section{Physical characteristics}

In Upland Pedons, the texture clayey at the surface and sandy clay at sub-surface in Bt horizon, whereas in lowland (P2) and midland (P4) black soil pedons, texture was clay throughout the profile. In the Deccan Plateau of India clay texture in black soil pedons is a common feature (Biswas and Gawande, 1992). Bulk of the particle size distribution in red soil pedons constituted of coarser fractions (more sand and coarse fragment), whereas in black soil pedon, bulk of it was constituted of finer particles due to more chemical weathering in the latter. More total sand in red soil could be attributed to the nature of parent rock, which is granite and granite gneiss complex containing more of quartz (Krishnamurthy, 1993). In red soil pedons bulk density slightly decreased in the Bt horizon, because of better soil aggregation due to increased microbial activity. In black soil pedons (P2, P4) bulk density was influenced by amount of clay and silt. In pedon 7, Bt4 horizon exhibited least value because of low clay and silt content (Goroji, 1994). Particle density is the amount of soil solids per given volume. In red and black soil pedons the amount of sand, silt, clay per given volume shown correlation with the values of particle density in pedon 4, Bw3 horizon shown least particle density values because of very low amount of course sand.

\section{Physico-chemical properties}

The $\mathrm{pH}$ values of soils ranged from 6.2 to 8.7 , and it was slightly acidic to strongly alkaline in reaction. It might be attributed to intense and uniform leaching of bases throughout the profile (Sitanggang et al., 2006). The lower $\mathrm{pH}$ indicates the high degree of leaching in the surface soil and its decrease in the subsequent horizons (Das and Roy, 1979) may be due to the predominance of electronegative colloids in the soil. It showed that weathering was not as advanced in these soils. The values of EC (1:2.5 soil water 


\section{International Journal of Science and Research (IJSR) \\ ISSN (Online): 2319-7064 \\ Index Copernicus Value (2013): 6.14 | Impact Factor (2015): 6.391}

ratio) ranged from 0.09 to $0.95 \mathrm{dS} \mathrm{m}-1$. Thus these soils are non-saline in nature. EC of all the pedons was very low due to the leaching caused by land slope and rainfall as observed by Sivasankaran et al (1993). The mean Organic carbon content in soil ranged from 0.21 to 0.33 per cent. Its content was low in all the pedons. Surface horizons recorded the high values and its values decreased with depth in all the pedons similar findings were reported by Pal et al. (1985).

Cation exchange capacity varied between the pedons and also between the horizons in each pedon. The CEC values of upland pedons were low (5.0 to $14 \mathrm{cmol}\left(\mathrm{p}^{+}\right) \mathrm{kg}-1$. The low CEC in the surface horizon was due to eluviation of bases, clay and silt to subsurface horizons and illuviation of kaolinite dominated clay to lower layers and accumulation of sesquioxides. Dominance of 1:1 type, kaolinitic clay was the reason for low CEC in these soils (Rajan, 2008). The base saturation was high in all the surface horizons, due to the influence of organic matter and in most of the profiles, showed tendency to increase with the depth and following the distribution pattern of $\mathrm{pH}$. The increase of base saturation with depth is due to the leaching of bases from the upper horizon and their deposition in the lower horizons owing to semi arid climate.

The available nitrogen, phosphorus and potassium content varied very much among the pedons. The available nitrogen varied from 50.3 to $197.0 \mathrm{~kg} \mathrm{ha}^{-1}$. The highest available nitrogen content present in pedon 2 where it ranged from 187 to $197 \mathrm{~kg} \mathrm{ha}^{-1}$. This was due to higher clay, so that the leaching less pronounced, assisted by continuous addition of fertilizers and increased level of organic matter for cultivation. The available phosphorus varied from 10.5 to $58.1 \mathrm{~kg} \mathrm{ha}^{-1}$. The phosphorous content decreased with depth and showed low status of available phosphorous with depth. This may be attributed to its higher removal than replenishment and also high phosphorous fixation capacity (Sathisha and Badrinath, 1994). The available potassium varied from 44.8 to $250 \mathrm{~kg} \mathrm{ha}^{-1}$. The highest available potassium content present in pedon 4 , where it ranged from 196 to $250 \mathrm{~kg} \mathrm{ha}^{-1}$. Lowest available potassium content was in pedon 5, where it ranged from 44.8 to $141.2 \mathrm{~kg} \mathrm{ha}^{-1}$. In all pedon soils available potassium content increased with the depth. Coarse textured and gravelly soils are particularly low in available potassium, possibly due to faster and deeper leaching as observed by Badrinath et al., (1986) in Puttur soils. The available sulphur ranged from 6.3 to 33.3 in all the pedons, it shown decreasing trend with increasing soil depth. The low land soil pedon (P2) and mid land soil pedon (P4) shown high values, when compared to all upland soil pedons. This may be due to the fact that amount of clay having net negative charges shown repulsion (Anionic repulsion) property to sulphate anion resulted in higher sulphur availability. The DTPA extractable Fe, $\mathrm{Mn}$ and $\mathrm{Cu}$ are in optimum range. Similar results were observed by Bhaskar et al. (2004) in hill slopes of Narang- Kongripara watershed of Meghalaya.

Concentration of micronutrients decreases with the depth. In all soil pedons, $\mathrm{Zn}$ content was below the critical level, which may be due to good drainage condition and better porosity, which played a critical role in zinc availability.
Similar results were recorded by Kannan and Mathan (1994) in Tamil Nadu soils.

\section{Conclusion}

Kannur watershed depth of the soils ranged from moderately deep to very deep, the solum thickness increased from upper to the lower slopes in the study area. The colour of the soils varied from reddish brown to dark red in uplands, this was found to be influenced mainly by the type of parent material, low organic matter content, warmer temperature regime and moderately high rainfall existing in the area. The colour varied from yellowish brown to dark grey in lowlands. This was influenced by the topography and impeded drainage in the sub-surface layers.

The study reveals that there is a close relationship between physiography and soils. The formation of the diverse group of soils can be attributed to the variation in topography, causing erosion, leaching, sedimentation and other pedogenic processes modified by altered water regime.

\section{References}

[1] Badrinath, M. S., Krishnan, A. M., Patil, B. N., Kenchaiah, K. and Balakrishna Rao, K., 1986. Fertility status of some typical soil sof coastal Karnataka. J. Indian Soc. Soil Sci., 34: 436-438.

[2] Bhaskar, B. P., Mishra, J. P., Baruah, U., Vadivelu, S., Sen, T. K., Butte, P. S. and Dutta, D. P., 2004. Soils on Jhum cultivated hill slopes of Narang - Kongripara watershed in Meghalaya. J. Indian Soc. Soil Sci., 52: 125- 133.

[3] Biswas, T. D. and Gawande, S. P., 1992. Studies on genesis of catenary soils on sedimentary formation in Chhatisgarh basin of Madhya Pradesh I. and mechanical composition. $J$. Indian Soc. Soil Sci., 10: 233-234.

[4] Das, S. N. and Roy, B. B., 1979. Characterization of catenary soil. Indian J.Agric.Chem., 12: 43-51.

[5] Dasog, G. S. and Hadimani, A. S., 1980. Genesis and chemical properties of some Vertisols. J. Indian Soc. Soil Sci., 28: 49-56.

[6] Food and Agricultural Organization (FAO), 1983. Guidelines: Land evaluation for rain fed agriculture.FAO, Rome.

[7] Goroji, P.T., 1994. Studies on physical and chemical properties of Vertisols of zones three and eight of Karnataka. M.Sc. (Agri.) Thesis, University of Agricultural Sciences, Dharwad.

[8] Indian Meteorological Department (IMD), 2012. Climatological Tables, 1980-1911, IMD, Pune, Controller of Publications, New Delhi, 782 p.

[9] Jackson, M. L. 1973. Soil Chemical Analysis, Prentice Hall of India Pvt Ltd. New Delhi

[10] Krishnamurthy, K. G., 1993. Properties, genesis and classification of red soil of North Karnataka. M. Sc. (Agri.) Thesis, Univ. Agric. Sci., Dharwad (India).

[11] Kannan, N. and Mathan, K.K., 1994. Iron, Manganese zinc and copper contents of some selected watershed in hilly regions of Tamil Nadu. Madras Agric. J., 81: 512-514.

[12] Pal, D. K., 1985. Potassium release from muscovite and biotite under alkaline conditions, Agropedology, 35: 133-136.

[13] Piper, C. S., 1944. Soil and Plant Analysis, Inter Science Publishers Inc. New York 369p.

[14] Rajan, K., 2008. Impact of erosion and salinity on soil and land quality indicators in southern Karnataka. Ph.D. (Agri.) thesis submitted to UAS, Bangalore. 


\section{International Journal of Science and Research (IJSR) ISSN (Online): 2319-7064 \\ Index Copernicus Value (2013): 6.14 | Impact Factor (2015): 6.391}

[15] Sathisha, G. C. and Badrinath, M.S., 1994. Characterization of soils of Western Ghats in Dakshina Kannada district, Karnataka. Agropedology, 4: 45-48.

[16] Sitanggang, Masri, Rao, V. S., Ahmed, Nayan and Mahapatra, S. K., 2006. Characterization and Classification of soils in watershed area of Shikolpur, Gurgaon district, Haryana. J. Indian Soc. Soil Sci., 54: 106-110.

[17] Sivasankaran, K., Badrinath, M. S., Natesan, S. and Subbarayappa, C.T., 1993. Physico-chemical properties and nutrient management of red and lateritic soils, crops in Southern India, NBSS Publications, 37 p. 280.

[18] Soil Survey Staff, 1951. Soil Survey Manual, Agriculture Handbook No.18, USBR, USDA, Washington D.C, 503pp.

[19] Soil Survey Staff, 2004. Soil Survey Manual, Agric. Handbook no. 18, (USDA: Washington, D.C) Published by Scientific Publishers, P.O. Box 91, Jodhpur, India.

[20] Walkley, A. and Black, I. A., 1934. An Examination of Degtjareff Method for Determining Soil Organic Matter and a
Proposed Modification of the Chromic Acid Titration Method. Soil Sci. 37: 29-37.

\section{Author Profile}

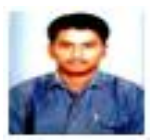

M. Ravindra Naik received the B.Sc(Agri) and M.Sc(Agri) Degrees in Agricultural sciences and specialization in Soil science and Agricultural chemistry as National research scholar from University Of Agricultural Sciences, Bangalore 2012 and 2014, respective degrees. During 2012-2014, he has done research in Application of RS tools and characterization, taxonomical classification of soils with collaboration of ${ }^{2}$ ICAR-National Bureau of Soil Science and Land Use Planning, R.C. Bangalore-560 024, Karnataka, India (NBSS \&LUP). He is now working with NBSS\&LUP.

\begin{tabular}{|c|c|c|c|c|c|c|c|c|c|c|c|c|c|c|c|c|c|}
\hline \multirow{2}{*}{\begin{tabular}{|c} 
Pedon \\
No \& \\
horizons
\end{tabular}} & \multirow{2}{*}{$\begin{array}{l}\text { Depth } \\
\text { (cm) }\end{array}$} & \multirow{2}{*}{$\begin{array}{c}\text { Colour } \\
\text { moist }\end{array}$} & \multirow[t]{2}{*}{ Texture } & \multicolumn{3}{|c|}{ Structure } & \multicolumn{4}{|c|}{ Consistence } & \multirow{2}{*}{\multicolumn{2}{|c|}{ Effervescence }} & \multicolumn{2}{|c|}{ Boundary } & pores & \multicolumn{2}{|c|}{ roots } \\
\hline & & & & $\mathrm{S}$ & G & $\mathrm{T}$ & Dry & Moist & Stickyness & Plasticity & & & $\mathrm{D}$ & T & \begin{tabular}{l|l}
$\mathrm{S}$ & $\mathrm{Q}$
\end{tabular} & $\mathrm{S}$ & Q \\
\hline \multicolumn{18}{|c|}{ isohyperthermic, Typic Kandiustalfs. } \\
\hline Ap & $0-26$ & 5YR 4/4 & scl & $\mathrm{m}$ & 2 & sbk & $\mathrm{sh}$ & $\mathrm{fr}$ & ss & $\mathrm{sp}$ & - & & $\mathrm{C}$ & $\mathrm{s}$ & $\mathrm{f}$ & $\mathrm{f}$ & $\mathrm{C}$ \\
\hline Bt1 & $26-47$ & $2.5 \mathrm{YR} 3 / 6$ & $\mathrm{C}$ & $\mathrm{m}$ & 2 & sbk & sh & fr & ss & $\mathrm{sp}$ & - & & C & $\mathrm{s}$ & $\mathrm{f}$ & $\mathrm{f}$ & $\mathrm{C}$ \\
\hline Bt2 & $47-66$ & $2.5 \mathrm{YR} 3 / 6$ & $\mathrm{C}$ & $\mathrm{m}$ & 2 & sbk & sh & $\mathrm{fr}$ & SS & $\mathrm{sp}$ & - & & $\mathrm{a}$ & $\mathrm{s}$ & $\mathrm{f}$ & $\mathrm{f}$ & $\mathrm{C}$ \\
\hline Bt3 & $66-102$ & $2.5 \mathrm{YR} 3 / 4$ & vgsc & $\mathrm{m}$ & 2 & sbk & $\mathrm{sh}$ & $\mathrm{fr}$ & SS & $\mathrm{sp}$ & - & & $\mathrm{g}$ & $\mathrm{s}$ & - & - & - \\
\hline Bt4 & $102-138$ & $2.5 \mathrm{YR} 3 / 4$ & vgsc & 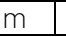 & 2 & sbk & sh & fr & ss & $\mathrm{sp}$ & - & & $\mathrm{g}$ & $\mathrm{w}$ & - & - & - \\
\hline \multicolumn{18}{|c|}{ Pedon 2 Fine, mixed, isohyperthermic, Typic Haplusterts. } \\
\hline $\mathrm{Ap}$ & $0-19$ & 10YR3/1 & $\mathrm{C}$ & C & 2 & sbk & $\mathrm{h}$ & fr & vs & $\mathrm{vp}$ & - & & $\mathrm{g}$ & $\mathrm{s}$ & $\mathrm{f}$ & $\mathrm{f}$ & $\mathrm{C}$ \\
\hline Bw & $19-42$ & 10YR3/1 & $\mathrm{C}$ & $\mathrm{C}$ & 2 & sbk & $\mathrm{h}$ & $\mathrm{fr}$ & vs & vp & - & & $\mathrm{g}$ & $\mathrm{s}$ & $\mathrm{f}$ & $\mathrm{f}$ & $\mathrm{C}$ \\
\hline Bss1 & $42-73$ & 10YR3/1 & $\mathrm{C}$ & $\mathrm{C}$ & 2 & sbk & $\mathrm{h}$ & $\mathrm{fr}$ & vs & $\mathrm{vp}$ & - & & $\mathrm{g}$ & $\mathrm{s}$ & f & $\mathrm{f}$ & $\mathrm{C}$ \\
\hline Bss2 & $73-99$ & 10YR3/1 & $\mathrm{C}$ & $\mathrm{C}$ & 2 & sbk & $\mathrm{h}$ & $\mathrm{fr}$ & vS & $\mathrm{vp}$ & - & & $\mathrm{g}$ & $\mathrm{w}$ & - & - & - \\
\hline Bss3 & $99-150$ & 10YR3/1 & $\mathrm{C}$ & $\mathrm{C}$ & 2 & sbk & $\mathrm{h}$ & fr & vs & vp & - & & $\mathrm{g}$ & $\mathrm{w}$ & - & - & - \\
\hline \multicolumn{18}{|c|}{ Pedon 3 Fine, kaolinitic isothermic, Kandic Paleustalfs. } \\
\hline Ap & $0-20$ & 5YR3/4 & $\mathrm{SC}$ & $\mathrm{m}$ & 2 & sbk & sh & fr & $\mathrm{ms}$ & $\mathrm{mp}$ & - & & C & $\mathrm{S}$ & $\mathrm{C}$ & $f$ & C \\
\hline Bt1 & $20-38$ & $2.5 \mathrm{YR} 3 / 6$ & C & $\mathrm{m}$ & 2 & sbk & sh & $\mathrm{fr}$ & $\mathrm{ms}$ & $\mathrm{mp}$ & - & & $g$ & $\mathrm{~s}$ & $\mathrm{f}$ & $\mathrm{f}$ & $\mathrm{C}$ \\
\hline Bt2 & $38-75$ & $2.5 \mathrm{YR} 3 / 6$ & $\mathrm{C}$ & $\mathrm{m}$ & 2 & sbk & $\mathrm{sh}$ & fr & $\mathrm{ms}$ & $\mathrm{mp}$ & - & & g & $\mathrm{s}$ & $\mathrm{f}$ & $\mathrm{f}$ & $\mathrm{C}$ \\
\hline Bt3 & $75-98$ & $2.5 \mathrm{YR} 3 / 4$ & $\mathrm{C}$ & $\mathrm{m}$ & 2 & sbk & sh & $\mathrm{fr}$ & $\mathrm{ms}$ & $\mathrm{mp}$ & - & & $\mathrm{g}$ & $\mathrm{s}$ & - & $\mathrm{f}$ & $\mathrm{C}$ \\
\hline Bt4 & 98-145 & $2.5 \mathrm{YR} 3 / 4$ & $\mathrm{C}$ & $\mathrm{m}$ & 2 & sbk & sh & fr & $\mathrm{ms}$ & $\mathrm{mp}$ & - & & $\mathrm{g}$ & $\mathrm{s}$ & - & & \\
\hline \multicolumn{18}{|c|}{ Pedon 4 Fine mixed isohyperthermic Oxic Haplustepts. } \\
\hline Ap & $0-16$ & 10YR4/ 6 & $\mathrm{C}$ & $\mathrm{m}$ & 2 & sbk & sh & fr & $\mathrm{ms}$ & $\mathrm{mp}$ & - & & $\mathrm{C}$ & $\mathrm{s}$ & $\mathrm{C}$ & $\mathrm{f}$ & $\mathrm{C}$ \\
\hline Bw1 & $16-57$ & $7.5 \mathrm{YR} 4 / 4$ & $\mathrm{C}$ & $\mathrm{m}$ & 2 & sbk & sh & $\mathrm{fr}$ & $\mathrm{ms}$ & $\mathrm{mp}$ & - & & $\mathrm{C}$ & $\mathrm{s}$ & $\mathrm{f}$ & $\mathrm{f}$ & $\mathrm{C}$ \\
\hline Bw2 & $57-78$ & $7.5 Y R 4 / 4$ & $\mathrm{C}$ & $\mathrm{m}$ & 2 & sbk & $\mathrm{sh}$ & $\mathrm{fr}$ & $\mathrm{ms}$ & $\mathrm{mp}$ & - & & $\mathrm{g}$ & $\mathrm{s}$ & $\mathrm{f}$ & $\mathrm{f}$ & $\mathrm{C}$ \\
\hline Bw3 & $78-105$ & 10YR4/3 & C & $\mathrm{m}$ & 2 & sbk & $\mathrm{sh}$ & $\mathrm{fr}$ & $\mathrm{ms}$ & $\mathrm{mp}$ & - & & g & $\mathrm{s}$ & $\mathrm{f}$ & $f$ & $\mathrm{C}$ \\
\hline Bw4 & $105-140$ & 10YR4/4 & $\mathrm{C}$ & $\mathrm{m}$ & 2 & sbk & sh & fr & $\mathrm{ms}$ & $\mathrm{mp}$ & - & & g & $\mathrm{s}$ & - & & \\
\hline Pedon & Fine, mixe & ed, isohypert & thermic, K & Kanha & aplic . & Rhodu & stalfs & & & & & & & & & & \\
\hline Ap & $0-19$ & \begin{tabular}{l|l}
$7.5 \mathrm{YR} 4 / 4$ \\
\end{tabular} & \begin{tabular}{|c|c|}
4 & scl
\end{tabular} & $\mathrm{m}$ & 1 & & bk & sh & SS & $\mathrm{sp}$ & - & $\mathrm{a}$ & $\mathrm{S}$ & $f$ & $\mathrm{C}$ & & \\
\hline Bt1 & $19-36$ & $2.5 \mathrm{YR} 3 / 4$ & $\mathrm{C}$ & $\mathrm{m}$ & 1 & & $\mathrm{bk}$ & sh & $\mathrm{ms}$ & $\mathrm{mp}$ & - & $\mathrm{C}$ & $\mathrm{s}$ & $f$ & $\mathrm{C}$ & & \\
\hline Bt2 & $36-82$ & $2.5 \mathrm{YR} 3 / \mathrm{k}$ & $\mathrm{C}$ & $\mathrm{m}$ & 1 & & $\overline{b k}$ & sh & $\mathrm{ms}$ & $\mathrm{mp}$ & - & $\mathrm{g}$ & $\mathrm{s}$ & $\mathrm{f}$ & $\mathrm{m}$ & & \\
\hline Bt3 & $82-121$ & $2.5 \mathrm{YR} 3 / \mathrm{t}$ & 6 & $\mathrm{~m}$ & 1 & & $\mathrm{bk}$ & sh & $\mathrm{ms}$ & $\mathrm{mp}$ & - & $\mathrm{g}$ & $\mathrm{s}$ & $\mathrm{f}$ & $\mathrm{m}$ & & \\
\hline Bt4 & 121-163 & 2.5YR3/ & C & $\mathrm{m}$ & 1 & & $\mathrm{bk}$ & sh & $\mathrm{ms}$ & $\mathrm{mp}$ & - & g & $\mathrm{s}$ & - & - & & \\
\hline Pedon & Fine, mixe & ed, iso-hyper & rthermic, 1 & Rhod & ic $\mathrm{Pa}$ & eusta & & & & & & & & & & & \\
\hline Ap & $0-20$ & \begin{tabular}{l|l} 
5YR4/4 \\
\end{tabular} & \begin{tabular}{l|l} 
& $\mathrm{scl}$
\end{tabular} & $\mathrm{m}$ & 2 & & $\overline{b k}$ & sh & SS & $\mathrm{sp}$ & - & $\mathrm{a}$ & $\mathrm{S}$ & $\mathrm{f}$ & $\mathrm{C}$ & $\mathrm{f}$ & C \\
\hline Bt1 & $20-41$ & 2.5YR3/ & $\mathrm{C}$ & $\mathrm{m}$ & 2 & & $\mathrm{bk}$ & sh & SS & $\mathrm{sp}$ & - & C & $\mathrm{s}$ & - & - & $\mathrm{f}$ & C \\
\hline Bt2 & $41-87$ & $2.5 \mathrm{YR} 3 / \mathrm{t}$ & $\mathrm{C}$ & $\mathrm{m}$ & 2 & & $\mathrm{bk}$ & sh & SS & $\mathrm{sp}$ & - & $g$ & $\mathrm{~s}$ & - & - & $\mathrm{f}$ & $\mathrm{C}$ \\
\hline Bt3 & $87-117$ & $2.5 \mathrm{YR} 3 / 4$ & C & $\mathrm{m}$ & 2 & & $\mathrm{bk}$ & sh & SS & $\mathrm{sp}$ & - & $\mathrm{g}$ & $\mathrm{s}$ & - & - & $\mathrm{f}$ & $\mathrm{C}$ \\
\hline Bt4 & 117-155 & \begin{tabular}{l|l} 
& $2.5 \mathrm{YR} 3 / 4$ \\
\end{tabular} & \begin{tabular}{|l|l|}
4 & $\mathrm{C}$ \\
\end{tabular} & $\mathrm{m}$ & 2 & & \begin{tabular}{l|l}
$\mathrm{bk}$ & \\
\end{tabular} & \begin{tabular}{l|l} 
sh & 1 \\
\end{tabular} & SS & $\mathrm{sp}$ & - & $\mathrm{g}$ & $\mathrm{s}$ & - & - & & \\
\hline Pedon & Clayey-ske & eletal, mixed, & d, iso-hype & erther & mic, & Kandi & $\mathrm{cPal}$ & eustalfs. & & & & & & & & & \\
\hline $\mathrm{Ap}$ & $0-17$ & $7.5 Y R 4 / 4$ & gsl & $\mathrm{m}$ & 1 & & $\mathrm{bk}$ & sh & So & po & - & $\mathrm{a}$ & $\mathrm{s}$ & $f$ & $\mathrm{C}$ & $\mathrm{f}$ & C \\
\hline Bt1 & $17-44$ & 5YR3/4 & gSC & $\mathrm{m}$ & 2 & & $\mathrm{bk}$ & sh & $\mathrm{ms}$ & $\mathrm{mp}$ & - & $\mathrm{C}$ & $\mathrm{s}$ & $\mathrm{f}$ & $\mathrm{f}$ & $\mathrm{f}$ & $\mathrm{C}$ \\
\hline Bt2 & $44-80$ & $2.5 \mathrm{YR} 3 / 4$ & gSC & $\mathrm{m}$ & 2 & & $\mathrm{bk}$ & sh & $\mathrm{ms}$ & $\mathrm{mp}$ & - & $\mathrm{g}$ & $\mathrm{s}$ & - & - & $\mathrm{f}$ & $\mathrm{C}$ \\
\hline Bt3 & $80-109$ & $2.5 \mathrm{YR} 3 / 4$ & egsc & $\mathrm{m}$ & 2 & & $\mathrm{bk}$ & sh & $\mathrm{ms}$ & $\mathrm{mp}$ & - & g & $\mathrm{s}$ & - & - & $\mathrm{f}$ & $\mathrm{C}$ \\
\hline Bt4 & 109-148 & \begin{tabular}{|c|}
$2.5 \mathrm{YR} 3 / 4$ \\
\end{tabular} & egsc & $\mathrm{m}$ & 2 & & $\mathrm{bk}$ & sh & $\mathrm{ms}$ & $\mathrm{mp}$ & - & $\mathrm{g}$ & $\mathrm{s}$ & - & - & & \\
\hline Pedon & Clayey-ske & eletal, mixed & d, iso-hype & erthel & rmic, & Kanh & aplic & Rhodust & talfs. & & & & & & & & \\
\hline $\mathrm{Ap}$ & $0-17$ & $2.5 \mathrm{YR} 3 / 6$ & $\mathrm{gc}$ & $\mathrm{m}$ & 2 & & $\mathrm{bk}$ & sh & $\mathrm{ms}$ & $\mathrm{mp}$ & - & $\mathrm{C}$ & $\mathrm{s}$ & $\mathrm{f}$ & $\mathrm{C}$ & $\mathrm{f}$ & C \\
\hline Bt1 & $17-45$ & $2.5 \mathrm{YR} 3 / 6$ & $\mathrm{gc}$ & $\mathrm{m}$ & 2 & & $\mathrm{bk}$ & sh & $\mathrm{ms}$ & $\mathrm{mp}$ & - & $\mathrm{g}$ & $\mathrm{s}$ & $f$ & $\mathrm{~m}$ & $\mathrm{f}$ & $\mathrm{C}$ \\
\hline Bt2 & 45-72 & $2.5 \mathrm{YR} 3 / 4$ & $\mathrm{vgC}$ & $\mathrm{m}$ & 2 & & $\mathrm{bk}$ & sh & $\mathrm{ms}$ & $\mathrm{mp}$ & ev & $\mathrm{a}$ & $\mathrm{s}$ & $\mathrm{f}$ & $\mathrm{m}$ & $\mathrm{f}$ & $\mathrm{C}$ \\
\hline Bt3 & $72-98$ & $2.5 \mathrm{YR} 3 / 4$ & egsc & $\mathrm{m}$ & 1 & & $\mathrm{bk}$ & sh & $\mathrm{ms}$ & $\mathrm{mp}$ & ev & $\mathrm{C}$ & $\mathrm{s}$ & - & - & $\mathrm{f}$ & C \\
\hline Bt4 & $98-130+$ & $2.5 \mathrm{YR} 3 / 4$ & egsc & $\mathrm{m}$ & 1 & & $\mathrm{bk}$ & sh & $\mathrm{ms}$ & $\mathrm{mp}$ & - & $\mathrm{C}$ & $\mathrm{s}$ & - & - & & \\
\hline
\end{tabular}




\section{International Journal of Science and Research (IJSR) \\ ISSN (Online): 2319-7064}

Index Copernicus Value (2013): 6.14 | Impact Factor (2015): 6.391

Table 2: Physico-chemical properties of the soils

\begin{tabular}{|c|c|c|c|c|c|c|c|c|c|c|}
\hline \multirow{2}{*}{$\begin{array}{l}\text { Pedon no \& } \\
\text { horizons }\end{array}$} & \multirow{2}{*}{$\begin{array}{l}\text { Depth in } \\
\text { (cm) }\end{array}$} & \multicolumn{3}{|l|}{ Texture } & \multirow{2}{*}{$\begin{array}{l}\text { Gravel } \\
\text { (\%) }\end{array}$} & \multirow{2}{*}{$\begin{array}{l}\text { B.D } \\
\text { (Mg } \\
\mathrm{m}-3)\end{array}$} & \multirow{2}{*}{$\begin{array}{l}\text { P.D } \\
(\mathrm{Mg} \\
\mathrm{m}-3)\end{array}$} & \multirow{2}{*}{$\begin{array}{l}\text { pH } \\
(1: 2.5)\end{array}$} & \multirow{2}{*}{$\begin{array}{l}\text { E.C } \\
(1: 2.5) \\
\left(\mathrm{dS} \mathrm{m}^{-1}\right)\end{array}$} & \multirow{2}{*}{$\begin{array}{l}\text { O.C } \\
\text { (\%) }\end{array}$} \\
\hline & & Sand \% & Silt \% & Clay \% & & & & & & \\
\hline & \multicolumn{10}{|c|}{ Pedon 1, Fine, kaolinitic, iso-hyperthermic, Typic Kandiustalfs. } \\
\hline $\mathrm{Ap}$ & $0-26$ & 52.34 & 20.86 & 26.80 & $1-5$ & 1.53 & 2.78 & 7.08 & 0.36 & 0.39 \\
\hline Bt1 & $26-47$ & 47.00 & 11.60 & 44.20 & $1-5$ & 1.65 & 2.95 & 6.83 & 0.27 & 0.34 \\
\hline Bt2 & $47-66$ & 44.44 & 7.86 & 47.70 & $5-10$ & 1.60 & 2.96 & 6.62 & 0.29 & 0.35 \\
\hline Bt3 & $66-102$ & 45.61 & 7.89 & 46.50 & 60 & 1.52 & 2.89 & 6.36 & 0.28 & 0.29 \\
\hline $\mathrm{Bt} 4$ & $102-138$ & 50.40 & 7.10 & 42.50 & 60 & 1.42 & 2.85 & 6.22 & 0.20 & 0.28 \\
\hline & \multicolumn{10}{|c|}{ Pedon 2, Fine, mixed, iso-hyperthermic, Typic Haplusterts. } \\
\hline Ap & 0-19 & 25.70 & 19.60 & 54.70 & $1-5$ & 1.47 & 2.89 & 8.72 & 0.45 & 0.45 \\
\hline Bw & $19-42$ & 19.00 & 22.30 & 58.70 & $1-5$ & 1.48 & 2.99 & 8.60 & 0.58 & 0.36 \\
\hline Bss1 & $42-73$ & 22.90 & 22.30 & 54.80 & $1-5$ & 1.43 & 2.97 & 8.06 & 0.53 & 0.32 \\
\hline Bss2 & 73-99 & 25.70 & 22.20 & 52.10 & $1-5$ & 1.42 & 2.80 & 8.12 & 0.44 & 0.28 \\
\hline Bss3 & 99-150 & 27.10 & 20.60 & 52.30 & $1-5$ & 1.42 & 2.90 & 7.76 & 0.38 & 0.26 \\
\hline & \multicolumn{10}{|c|}{ Pedon 3, Fine, kaolinitic, iso-hyperthermic, Kandic Paleustalfs. } \\
\hline Ap & $0-20$ & 45.60 & 16.90 & 37.50 & $1-5$ & 1.56 & 2.73 & 7.15 & 0.29 & 0.48 \\
\hline Bt1 & $20-38$ & 44.90 & 14.30 & 40.80 & $1-5$ & 1.66 & 2.90 & 7.12 & 0.24 & 0.34 \\
\hline Bt2 & 38-75 & 43.70 & 13.85 & 42.45 & $1-5$ & 1.67 & 2.92 & 7.10 & 0.19 & 0.25 \\
\hline Bt3 & $75-98$ & 42.30 & 13.60 & 44.10 & $1-5$ & 1.53 & 2.85 & 7.03 & 0.14 & 0.22 \\
\hline $\mathrm{Bt} 4$ & 98-145 & 41.60 & 12.65 & 45.75 & $1-5$ & 1.41 & 2.64 & 6.53 & 0.10 & 0.18 \\
\hline & \multicolumn{10}{|c|}{ Pedon 4, Fine, mixed, iso-hyperthermic, Oxic Haplustepts. } \\
\hline Ap & $0-16$ & 27.0 & 27.4 & 45.5 & $1-5$ & 1.46 & 2.51 & 8.04 & 0.40 & 0.65 \\
\hline Bw1 & $16-57$ & 23.2 & 28.2 & 48.6 & $1-5$ & 1.40 & 2.64 & 8.42 & 0.38 & 0.69 \\
\hline Bw2 & $57-78$ & 15.9 & 34.2 & 49.9 & $1-5$ & 1.41 & 2.64 & 8.47 & 0.33 & 0.55 \\
\hline Bw3 & 78-105 & 11.4 & 36.0 & 52.6 & $1-5$ & 1.39 & 1.99 & 8.36 & 0.24 & 0.41 \\
\hline Bw4 & $105-140$ & 10.1 & 33.3 & 56.6 & $1-5$ & 1.34 & 2.08 & 8.38 & 0.18 & 0.46 \\
\hline & \multicolumn{10}{|c|}{ Pedon 5, Fine, mixed, iso-hyperthermic, Kanhaplic Rhodustalfs. } \\
\hline Ap & $0-19$ & 50.80 & 20.70 & 28.50 & $1-5$ & 1.36 & 2.64 & 6.71 & 0.29 & 0.32 \\
\hline Bt1 & $19-36$ & 39.30 & 12.80 & 47.90 & $1-5$ & 1.43 & 2.79 & 6.86 & 0.24 & 0.30 \\
\hline Bt2 & $36-82$ & 42.20 & 12.00 & 45.80 & $1-5$ & 1.20 & 2.48 & 6.75 & 0.20 & 0.27 \\
\hline Bt3 & $82-121$ & 44.00 & 10.70 & 45.30 & $1-5$ & 1.39 & 2.62 & 6.84 & 0.15 & 0.16 \\
\hline $\mathrm{Bt} 4$ & $121-163$ & 50.50 & 9.00 & 40.50 & $1-5$ & 1.51 & 2.90 & 6.25 & 0.09 & 0.11 \\
\hline & \multicolumn{10}{|c|}{ Pedon 6, Fine, mixed, iso-hyperthermic, Rhodic Paleustalfs. } \\
\hline Ap & $0-20$ & 53.70 & 11.50 & 34.80 & $1-5$ & 1.71 & 2.71 & 7.6 & 0.95 & 0.43 \\
\hline Bt1 & $20-41$ & 45.00 & 12.20 & 42.80 & $1-5$ & 1.61 & 2.7 & 7.8 & 0.86 & 0.32 \\
\hline Bt2 & $41-87$ & 47.50 & 10.00 & 42.50 & $1-5$ & 1.55 & 2.58 & 7.7 & 0.46 & 0.31 \\
\hline Bt3 & $87-117$ & 48.10 & 8.30 & 43.60 & $1-5$ & 1.44 & 2.53 & 7.5 & 0.42 & 0.27 \\
\hline $\mathrm{Bt} 4$ & 117-155 & 53.20 & 7.10 & 39.70 & $1-5$ & 1.40 & 2.03 & 6.9 & 0.31 & 0.21 \\
\hline & \multicolumn{10}{|c|}{ Pedon 7, Clayey-skeletal, mixed, iso-hyperthermic, Kandic Paleustalfs. } \\
\hline Ap & $0-17$ & 55.9 & 21.6 & 22.5 & $15-35$ & 1.28 & 2.56 & 6.69 & 0.22 & 0.39 \\
\hline Bt1 & $17-44$ & 51.00 & 10.0 & 39.0 & $15-35$ & 1.30 & 2.62 & 6.80 & 0.38 & 0.28 \\
\hline Bt2 & $44-80$ & 50.71 & 9.19 & 40.10 & $15-35$ & 1.31 & 2.65 & 7.01 & 0.34 & 0.19 \\
\hline Bt3 & 80-109 & 49.90 & 9.00 & 40.10 & $>60$ & 1.21 & 2.37 & 6.75 & 0.28 & 0.11 \\
\hline $\mathrm{Bt} 4$ & 109-148 & 55.10 & 9.10 & 35.80 & $>60$ & 1.19 & 2.37 & 6.75 & 0.19 & 0.08 \\
\hline & \multicolumn{10}{|c|}{ Pedon 8, Clayey-skeletal, mixed, iso-hyperthermic, Kanhaplic Rhodustalfs. } \\
\hline Ap & $0-17$ & 38.05 & 13.50 & 48.40 & $15-35$ & 1.51 & 2.75 & 6.35 & 0.87 & 0.45 \\
\hline Bt1 & $17-45$ & 39.41 & 12.30 & 49.20 & 15-35 & 1.66 & 2.80 & 6.45 & 0.86 & 0.31 \\
\hline Bt2 & $45-72$ & 38.48 & 11.90 & 49.20 & 60 & 1.71 & 2.90 & 7.00 & 0.81 & 0.26 \\
\hline Bt3 & $72-98$ & 38.28 & 11.70 & 49.40 & $>60$ & 1.40 & 2.70 & 7.40 & 0.78 & 0.19 \\
\hline Bt4 & 98-130 & 46.68 & 10.82 & 45.40 & $>60$ & 1.32 & 2.65 & 7.79 & 0.65 & 0.14 \\
\hline
\end{tabular}




\section{International Journal of Science and Research (IJSR) \\ ISSN (Online): 2319-7064}

Index Copernicus Value (2013): 6.14 | Impact Factor (2015): 6.391

Table 3. Available nutrient status of the soils.

\begin{tabular}{|c|c|c|c|c|c|c|c|c|c|c|c|c|c|c|c|c|c|c|}
\hline \multirow[t]{2}{*}{$\begin{array}{l}\text { Depth } \\
\text { (cm) }\end{array}$} & \multirow[t]{2}{*}{ Horizon } & \multicolumn{4}{|c|}{$\begin{array}{l}\text { Exchangeable bases } \\
(\mathrm{cmol}(\mathrm{p}+) \mathrm{kg}-1)\end{array}$} & \multirow[t]{2}{*}{$\begin{array}{c}\text { Sum of } \\
\text { Bases }\end{array}$} & \multirow{2}{*}{$\begin{array}{c}\text { CEC } \\
(\mathrm{NH} 4 \mathrm{OAC}) \\
(\mathrm{cmol}(\mathrm{p}+) \\
\mathrm{kg}-1) \\
\end{array}$} & \multirow[t]{2}{*}{$\begin{array}{l}\text { ESP } \\
(\%)\end{array}$} & \multirow[t]{2}{*}{$\begin{array}{l}\text { BS } \\
(\%)\end{array}$} & \multirow[t]{2}{*}{ CEC/Clay } & \multicolumn{3}{|c|}{$\begin{array}{c}\text { Available } \\
\text { Macronutrients } \\
\left(\mathrm{Kg} \mathrm{ha}^{-1}\right)\end{array}$} & \multirow{2}{*}{$\begin{array}{c}\text { Secondary } \\
\text { Nutrient (mg } \\
\left.\mathrm{kg}^{-1}\right) \\
\mathrm{S} \\
\end{array}$} & \multicolumn{4}{|c|}{$\begin{array}{c}\text { Available } \\
\text { micronutrients } \\
\left(\mathrm{mg} \mathrm{kg}^{-1}\right)\end{array}$} \\
\hline & & $\mathrm{Ca}$ & $\mathrm{Mg}$ & $\mathrm{K}$ & $\mathrm{Na}$ & & & & & & $\mathrm{N}$ & $\mathrm{P}_{2} \mathrm{O}_{5}$ & $\mathrm{~K}_{2} \mathrm{O}$ & & $\mathrm{Cu}$ & $\mathrm{Fe}$ & $\mathrm{Mn}$ & $\mathrm{Zn}$ \\
\hline \multicolumn{19}{|c|}{ Pedon 1 Fine, kaolinitic, iso-hyperthermic, Typic Kandiustalfs. } \\
\hline Ap & $0-26$ & 3.12 & 1.99 & 1.87 & 0.01 & 3.13 & 8.01 & 0.12 & 39.07 & 0.30 & 139 & 18.60 & 146.23 & 18.05 & 2.64 & 5.68 & 16.52 & 0.08 \\
\hline Bt1 & $26-47$ & 2.64 & 1.88 & 1.81 & 0.23 & 2.87 & 8.31 & 2.76 & 34.53 & 0.19 & 105 & 14.58 & 141.54 & 17.05 & 1.62 & 3.38 & 11.52 & 0.22 \\
\hline Bt2 & $47-66$ & 2.44 & 1.81 & 1.66 & 0.22 & 2.66 & 6.78 & 3.24 & 39.23 & 0.14 & 110 & 11.51 & 129.81 & 14.58 & 1.34 & 3.58 & 10.62 & 0.08 \\
\hline Bt3 & 66-102 & 2.17 & \begin{tabular}{|l|}
0.72 \\
\end{tabular} & 1.53 & 0.21 & 2.38 & 5.31 & 3.95 & 44.82 & 0.12 & 98 & 11.00 & 119.64 & 11.88 & 0.96 & 2.72 & 9.84 & 1.52 \\
\hline Bt4 & $102-138$ & 2.00 & 0.66 & 1.15 & 0.19 & 2.19 & 5.04 & 5.04 & 3.76 & 0.11 & 94 & 10.50 & 89.93 & 9.59 & 0.85 & 2.08 & 9.00 & 0.60 \\
\hline \multicolumn{19}{|c|}{ Pedon 2 Fine, mixed, iso-hyperthermic, Typic Haplusterts. } \\
\hline Ap & $0-19$ & 12.7 & 8.50 & 1.73 & 1.05 & 23.99 & 33.99 & 3.09 & 70.58 & 0.60 & 197 & 58.1 & 135.98 & 31.94 & 2.18 & 7.28 & 4.79 & 0.12 \\
\hline Bw & $19-42$ & 11.1 & 6.40 & 1.62 & 0.95 & 20.07 & 30.07 & 3.15 & 66.75 & 0.53 & 192 & 41.6 & 131.92 & 27.08 & 1.80 & 4.74 & \begin{tabular}{|l|}
3.87 \\
\end{tabular} & 0.42 \\
\hline Bss1 & $42-73$ & 10.5 & 6.30 & 1.68 & 0.94 & 19.42 & 29.42 & 3.20 & 66.01 & 0.50 & 188 & 23.24 & 127.23 & 22.22 & 1.60 & 5.36 & 4.42 & 0.48 \\
\hline Bss2 & 73-99 & 8.60 & 5.20 & 1.42 & 0.89 & 16.11 & 26.11 & 3.42 & 61.71 & 0.48 & 187 & 22.60 & \begin{tabular}{|l|l}
111.27 \\
\end{tabular} & 21.52 & 1.54 & 4.84 & 4.46 & 0.36 \\
\hline Bss3 & 99-150 & 8.10 & 5.20 & 1.36 & 0.86 & 15.53 & 25.53 & 3.38 & 60.83 & & \begin{tabular}{|l|}
187 \\
\end{tabular} & 22.02 & 107.05 & 14.58 & 1.12 & 4.71 & \begin{tabular}{|l|}
4.43 \\
\end{tabular} & 0.30 \\
\hline \multicolumn{19}{|c|}{ Pedon 3, Fine, kaolinitic, iso-hyperthermic, Kandic Paleustalfs. } \\
\hline Ap & $0-20$ & 2.92 & 0.92 & 1.23 & 0.45 & 5.52 & 7.02 & 6.41 & 78.63 & 0.19 & 175 & 28.2 & 96.18 & 21.52 & 0.84 & 9.16 & \begin{tabular}{|l|l|}
8.82 \\
\end{tabular} & 0.28 \\
\hline Bt1 & $20-38$ & 4.98 & 3.63 & 1.01 & 0.51 & 10.13 & 11.63 & 4.38 & 87.10 & 0.28 & 168 & 27.5 & 78.98 & 14.58 & 0.82 & 7.20 & 11.52 & 0.31 \\
\hline Bt2 & 38-75 & 4.79 & 1.97 & 0.89 & 0.53 & 8.18 & 9.68 & 5.47 & 84.50 & 0.22 & 164 & 20.3 & 69.59 & 13.19 & 0.74 & 6.66 & 10.62 & 0.32 \\
\hline Bt3 & 75-98 & 1.96 & 1.56 & 0.8 & 0.25 & 4.57 & 6.07 & 4.11 & 75.28 & 0.14 & 142 & 18.9 & 62.56 & 10.41 & 0.68 & 5.94 & 9.58 & 0.28 \\
\hline Bt4 & 98-145 & 1.94 & 0.54 & 0.74 & 0.1 & 3.32 & 4.82 & 2.07 & 68.87 & 0.11 & 105 & \begin{tabular}{|l|}
18.4 \\
\end{tabular} & 57.86 & 6.25 & 0.6 & 4.02 & \begin{tabular}{|l|}
8.74 \\
\end{tabular} & 0.24 \\
\hline \multicolumn{19}{|c|}{ Pedon 4 Fine, mixed, iso-hyperthermic, Oxic Haplustepts. } \\
\hline $\mathrm{Ap}$ & $0-16$ & 3.2 & 1.7 & 0.17 & 1.3 & 6.37 & 11.14 & 11.66 & 57.14 & 0.24 & 125.4 & 41.5 & 250 & 33.33 & 3.24 & 13.8 & 16.10 & 0.22 \\
\hline Bw1 & $16-57$ & 4.2 & 2 & 0.51 & 1.8 & 8.51 & 13.61 & 13.21 & 62.50 & 0.28 & 87.7 & 30.5 & 252 & 32.63 & 1.78 & 12.6 & 18.00 & 0.18 \\
\hline Bw2 & $57-78$ & 3.3 & 1.5 & 0.4 & 1.4 & 6.60 & 9.90 & 14.14 & 66.66 & 0.20 & 59.6 & 22.5 & 205 & 27.77 & 1.60 & 9.20 & 14.00 & 0.17 \\
\hline Bw3 & 78-105 & 2.1 & 1 & 0.34 & 0.7 & 4.14 & 6.21 & 11.27 & 66.66 & 0.12 & 53.3 & 22.0 & 200 & 20.13 & 1.44 & 7.60 & 13.80 & 0.18 \\
\hline Bw4 & $105-140$ & 2.5 & 0.8 & 0.37 & 0.8 & 4.47 & 6.70 & 11.93 & 66.66 & 0.12 & 34.5 & 20.5 & 196 & 18.05 & 1.12 & 7.10 & 13.20 & 0.12 \\
\hline & & & & & & Pedon & ine, mi & SO- & ypertne & $\mathrm{IC}, \mathrm{K}$ & taplic I & Rhodus & talfs. & & & & & \\
\hline Ap & $0-19$ & 3.92 & 1.17 & 1.92 & 0.68 & 7.69 & 8.06 & 8.43 & 95.40 & 0.28 & 116.0 & 25.2 & 141.2 & 18.05 & 0.6 & 5.7 & 7.04 & 0.16 \\
\hline Bt1 & $19-36$ & 7.86 & 2.88 & 1.89 & 0.81 & 13.44 & 14.58 & 5.55 & 92.18 & 0.30 & 109.8 & 27.8 & \begin{tabular}{|l|}
99.87 \\
\end{tabular} & 17.77 & 0.56 & 4.9 & 8.92 & 0.24 \\
\hline Bt2 & $36-82$ & 5.98 & 2.22 & 1.01 & 0.70 & 9.91 & 10.31 & 9.79 & 96.12 & 0.2 & 69.0 & 21.2 & 75.24 & 15.41 & 2.08 & 3.3 & 5.8 & 0.1 \\
\hline Bt3 & $82-121$ & 1.96 & 0.81 & 1.00 & 0.40 & 4.17 & 4.21 & 9.50 & 99.04 & 0.10 & 50.3 & 15.9 & 55.24 & 9.52 & 2.96 & 5.28 & 7 & 0.08 \\
\hline Bt4 & 121-163 & 1.92 & 0.75 & 0.8 & 0.28 & 3.75 & 4.20 & 6.46 & \begin{tabular}{|l|}
6.46 \\
\end{tabular} & 0.10 & 54.2 & 14.6 & 44.8 & 7.91 & 2.42 & 4.72 & 8.6 & 0.06 \\
\hline & & & & & & Pedo & Fine, $n$ & d, iso & hypert & ermic, Rl & odic $P$ & aleusta & & & & & & \\
\hline $\mathrm{Ap}$ & -20 & 4.32 & 1.33 & 1.64 & 0.54 & 7.83 & 9.23 & 5.85 & 84.83 & 0.27 & 142.5 & 33.00 & 128.24 & 15.13 & 0.96 & 4.52 & 9.5 & 0.23 \\
\hline Bt1 & 20-41 & 5.62 & 1.59 & 1.45 & 0.7 & 9.36 & 10.76 & 6.50 & 86.98 & 0.25 & 120.4 & 23.86 & \begin{tabular}{|l|}
113.39 \\
\end{tabular} & 11.5 & 0.74 & 5.2 & 8.2 & 0.28 \\
\hline Bt2 & $1-87$ & 6.9 & 2.2 & 1.08 & 0.68 & 10.86 & 12.26 & 5.54 & 88.58 & 0.29 & 96.50 & 21.60 & 84.45 & 10.13 & 0.62 & 5.9 & 7.8 & 0.28 \\
\hline Bt3 & 87-117 & 3.21 & 1.9 & 0.93 & 0.42 & 6.46 & 7.86 & 5.34 & 82.18 & 0.19 & 89.90 & 20.40 & 72.72 & 8.74 & 0.85 & 4.42 & 6.4 & 0.22 \\
\hline Bt4 & 117-155 & 2.05 & 0.5 & 0.79 & 0.22 & 3.56 & 4.96 & 4.35 & \begin{tabular}{|l|l|}
71.77 \\
\end{tabular} & 0.12 & 85.00 & 19.78 & 61.77 & 7.36 & 0.74 & 3.46 & 5.6 & 0.12 \\
\hline & & & & & $\mathbf{P e}$ & don $7 \mathrm{C}$ & ey-skele & mixe & , iso-h & nypertherm & ic, Kan & idic Pal & eustalfs. & & & & & \\
\hline $\mathrm{Ap}$ & $0-17$ & 3.63 & 1.91 & 1.43 & 0.65 & 7.62 & 8.26 & 7.86 & 92.19 & 0.37 & 192.5 & 42.21 & 111.82 & 12.88 & 2.66 & 4.58 & 8.3 & 0.34 \\
\hline Bt1 & $17-44$ & 3.33 & 1.41 & 1.38 & 0.53 & 6.65 & 7.45 & 7.11 & 93.53 & 0.19 & 170.3 & 39.15 & 107.91 & 12.3 & 2.98 & 4.66 & 7.1 & 0.45 \\
\hline Bt2 & $44-80$ & 3.88 & 1.40 & 1.21 & 0.44 & 6.93 & 8.34 & 5.27 & 83.09 & 0.21 & 99.70 & 32.46 & 94.62 & 9.22 & 2.04 & 3.94 & 6.8 & 0.45 \\
\hline Bt3 & 80-109 & 3.33 & 0.88 & 0.93 & 0.38 & 5.52 & 6.04 & 6.29 & 91.39 & 0.15 & 89.09 & 28.72 & 72.72 & 7.49 & 1.94 & 3.86 & 5.6 & 0.39 \\
\hline Bt4 & 109-148 & 3.33 & 0.53 & 0.82 & 0.29 & 4.97 & 5.92 & 4.89 & 83.95 & 0.17 & 75.00 & 19.04 & 64.12 & 6.61 & 1.76 & 2.64 & 4.6 & 0.29 \\
\hline & & & & & Pedo & n 8 Clay & -skeletal, & ixed, & iso-hyp & perthermic & Kanhä & aplic Rl & nodustal & & & & & \\
\hline Ap & $0-17$ & 5.27 & 5.90 & 0.16 & 1.07 & 11.4 & 12.24 & 8.74 & 93.13 & 0.25 & \begin{tabular}{|l|l|}
127.8 \\
\end{tabular} & 39.15 & 122.30 & 14.91 & 1.82 & 5.92 & 7.79 & 0.16 \\
\hline Bt1 & $17-45$ & 5.14 & 4.20 & 0.14 & 1.15 & 9.63 & 10.47 & 10.98 & 91.97 & 0.22 & 99.40 & 28.75 & 113.00 & 13.02 & 2.08 & 7.08 & 10.26 & 0.26 \\
\hline Bt2 & $45-72$ & 4.05 & 3.09 & 0.13 & 1.08 & 6.37 & 8.21 & 13.15 & 77.58 & 0.17 & 92.40 & \begin{tabular}{|l|}
18.77 \\
\end{tabular} & 104.83 & 10.04 & 1.72 & 8.86 & 9.90 & 0.18 \\
\hline Bt3 & 72-98 & 4.05 & 2.90 & 0.13 & 0.55 & 6.09 & 6.93 & 7.93 & 87.87 & 0.14 & 75.40 & 17.34 & 94.60 & 10.94 & 1.64 & 2.75 & \begin{tabular}{|l|}
7.77 \\
\end{tabular} & 0.17 \\
\hline Bt4 & 98-130 & 2.40 & 1.50 & 0.12 & 0.31 & 3.83 & 4.67 & 6.63 & 82.01 & 0.10 & 72.70 & 13.6 & 87.00 & 9.44 & 1.47 & 2.40 & 6.64 & 0.15 \\
\hline
\end{tabular}

